\title{
Adhesive Catechol-Conjugated Hyaluronic Acid for Biomedical Applications: A Mini Review
}

\author{
Jongho Kim ${ }^{1}\left(\mathbb{D}\right.$, Chaemyeong Lee $^{2}$ and Ji Hyun Ryu ${ }^{3, *(1)}$ \\ 1 Carbon Composite Materials Research Center, Institute of Advanced Composite Materials, Korea Institute of \\ Science and Technology (KIST), Wanju, Jeonbuk 55324, Korea; jh-kim@kist.re.kr \\ 2 Department of Chemical and Biomolecular Engineering, Yonsei University, Seoul 03722, Korea; \\ leeyukyoung@yonsei.ac.kr \\ 3 Department of Carbon Convergence Engineering, Wonkwang University, Iksan, Jeonbuk 54538, Korea \\ * Correspondence: jhryu4816@wku.ac.kr; Tel.: +82-63-850-7273
}

check for

updates

Citation: Kim, J.; Lee, C.; Ryu, J.H. Adhesive Catechol-Conjugated Hyaluronic Acid for Biomedical Applications: A Mini Review. Appl. Sci. 2021, 11, 21. https://dx.doi.org/ 10.3390/app11010021

Received: 29 November 2020 Accepted: 19 December 2020 Published: 22 December 2020

Publisher's Note: MDPI stays neutral with regard to jurisdictional claims in published maps and institutional affiliations.

Copyright: () 2020 by the authors. Licensee MDPI, Basel, Switzerland. This article is an open access article distributed under the terms and conditions of the Creative Commons Attribution (CC BY) license (https: / / creativecommons.org / licenses/by/4.0/).

\begin{abstract}
Recently, catechol-containing polymers have been extensively developed as promising materials for surgical tissue adhesives, wound dressing, drug delivery depots, and tissue engineering scaffolds. Catechol conjugation to the polymer backbone provides adhesive properties to the tissue and does not significantly affect the intrinsic properties of the polymers. An example of a catecholic polymer is catechol-conjugated hyaluronic acid. In general, hyaluronic acid shows excellent biocompatibility and biodegradability; thus, it is used in various medical applications. However, hyaluronic acid alone has poor mechanical and tissue adhesion properties. Catechol modification considerably increases the mechanical and underwater adhesive properties of hyaluronic acid, while maintaining its biocompatibility and biodegradability and enabling its use in several biomedical applications. In this review, we briefly describe the synthesis and characteristics of catechol-modified hyaluronic acid, with a specific focus on catechol-involving reactions. Finally, we discuss the basic concepts and therapeutic effects of catechol-conjugated hyaluronic acid for biomedical applications.
\end{abstract}

Keywords: bio-inspired; adhesive; hyaluronic acid; catechol; dopamine

\section{Introduction}

Hyaluronic acid (HA) is a naturally occurring polysaccharide composed of D-glucuronic acid and $N$-acetyl-D-glucosamine, which is used in various biomedical applications, such as wound healing, viscosupplementation for wrinkle fillers, post-surgical antiadhesive barriers, drug delivery carriers, and tissue engineering scaffolds [1-13]. HA is abundantly found in connective tissues and fluids, particularly in articular cartilage and synovial fluids [1-5]. The roles of HA in biological functions are diverse, including the hydration of the extracellular matrix, the regulation of tissue homeostasis, receptor-mediated regulation of cell proliferation, migration, and differentiation, and the lubrication of cartilage and of the eyes [14,15]. For instance, HA in synovial fluids is responsible for the lubrication of cartilage in the synovium owing to its viscoelasticity and biocompatibility with synovial fluids [16]. In addition, HA is fully degraded by hyaluronidase in the body [17]. As a result, HA is widely used for drug delivery depots and tissue engineering scaffolds. However, there are difficulties in using unmodified HA in various medical settings due to its poor mechanical properties. Therefore, chemical modifications of the amine, thiol, and catechol functional groups on the HA backbone can address this drawback.

Marine mussels strongly adhere to various organic and inorganic surfaces (e.g., metal, metal oxides, ceramics, and polymer surfaces) by the secretion of mussel adhesive proteins via catechol-based reactions in wet environments (i.e., seawater) [18-22]. These involve the catechol side chains of 3,4-dihydroxy-L-phenylalanine (DOPA), an uncommon amino acid abundantly found in mussel adhesive proteins [18-22]. The catechol groups are oxidized 
at basic $\mathrm{pH}$ and are transformed into catechol quinones, which can react with various functional groups, including thiols, amines, and other catechols [23-25]. In addition to forming covalent bonds, the catechol groups interact with various substrates via electrostatic interactions, hydrogen bonds, $\pi-\pi$ stacking, and $\pi$-cation interactions $[25,26]$. Inspired by the mussel adhesion behavior, catechol-conjugated polymers have been synthesized to improve adhesion of fluids [27-31]. For instance, catechol-conjugated chitosan has excellent solubility at neutral $\mathrm{pH}$, excellent adhesive properties in tissues, and superior hemostatic capability compared to unmodified chitosan [32-36]. Therefore, the introduction of catechol groups into the HA backbone can increase HA mechanical properties and adhesiveness in wet environments.

In this review, we briefly describe the methodologies used for the preparation and characterization of HA-catechol. In addition, we focus on the biomedical uses of HAcatechol, which are categorized into the following four subsections: antifouling, wound healing, drug/gene delivery carriers, and tissue engineering scaffolds. Furthermore, we discuss the current challenges and opportunities for technologies using HA-catechol, which require further fundamental research, and its use in translational medicine.

\section{Methodologies for the Synthesis and Characterization of Hyaluronic Acid-Catechol}

Carbodiimide chemistry is commonly used to prepare HA-catechol [37-81]. It involves the formation of an amide bond between the carboxylic group of HA and the primary amine of dopamine (Figure 1a). The important reaction conditions for HA-catechol synthesis include maintaining the $\mathrm{pH}$ between 4 and 6 to prevent oxidation of the catechol groups [37]. The reaction solution turns black at a $\mathrm{pH}$ above 6, indicating the oxidation of the catechol groups. The degree of catechol substitution (DS) in HA is 10-35\%, identified using standard carbodiimide chemistry. Similar approaches have been used to prepare catechol-conjugated negatively charged polymers (i.e., alginate-catechol [82,83], heparincatechol [84], and polyacrylic acid-catechol [85]). In a previous study, a Schiff's base reaction between aldehyde-modified HA and dopamine was used to prepare HA-catechol [86]. HA was first oxidized using sodium periodate to prepare dialdehyde-functionalized HA. The formation of the Schiff base was achieved by the reaction between dialdehyde groups in oxidized HA and the primary amine groups in dopamine. The DS (25-45\%) obtained using the Schiff base reaction was higher than that obtained using the carbodiimide coupling reaction $(\sim 10 \%)$, probably due to the dialdehyde groups of the oxidized HA [86].

Synthesized HA-catechols can be characterized using ${ }^{1} \mathrm{H}-\mathrm{NMR}$ and UV-Vis spectroscopy. Figure $1 \mathrm{~b}$ shows the ${ }^{1} \mathrm{H}-\mathrm{NMR}$ spectrum of HA-catechol. HA peaks have been previously assigned as follows: the $\mathrm{N}$-acetyl peak at $2.0 \mathrm{ppm}$, and multiplets of disaccharide units and anomeric protons at 2.8-3.7 ppm [38-43]. In addition, the catechol protons were assigned to the peaks at 6.5-7.0 ppm [38-43]. The degree of catechol substitution was calculated by comparing the integrated area of the catechol protons $\left(3 \mathrm{H}, 6.5-7.0 \mathrm{ppm}, \mathrm{D}_{2} \mathrm{O}\right)$ and acetyl groups $\left(3 \mathrm{H},-\mathrm{COCH}_{3}, 2.0 \mathrm{ppm}, \mathrm{D}_{2} \mathrm{O}\right)$. In $\mathrm{UV}-\mathrm{Vis}$ spectroscopic studies, catechol groups show maximum absorption at a wavelength of $280 \mathrm{~nm}$ (Figure 1c). Catechol content can be quantified using standard curves of catechol concentrations constructed using a standard solution of dopamine $[37,38,44,45]$. Fourier transform infrared spectroscopy is also used to confirm the catechol conjugation of HA-catechol [38]. The peaks at 1720, 1630, and $1410 \mathrm{~cm}^{-1}$ are assigned to $\mathrm{C}=\mathrm{O}$, amine bonds, and $\mathrm{C}-\mathrm{O}$ stretching in $\mathrm{HA}-\mathrm{catechol}$, respectively. In addition, $\mathrm{C}-\mathrm{H}$ vibration $\left(2850 \mathrm{~cm}^{-1}\right)$ and $\mathrm{C}=\mathrm{C}$ ring stretching $\left(1520 \mathrm{~cm}^{-1}\right)$ indicate catechol conjugation on the HA backbone. 
a<smiles>NCCc1ccc(O)c(O)c1</smiles>

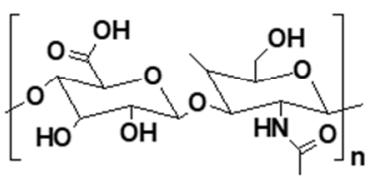

Hyaluronic acid $(\mathrm{HA})$

b

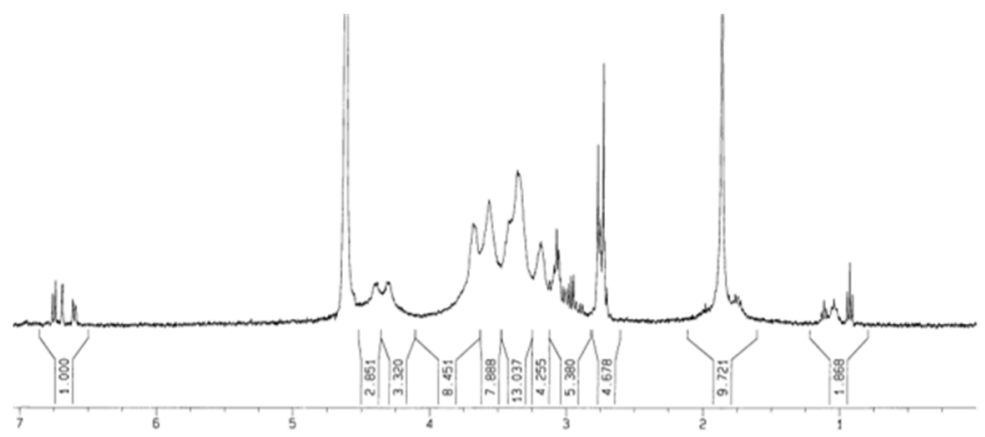

Hyaluronic acid-catechol (HA-catechol)

C

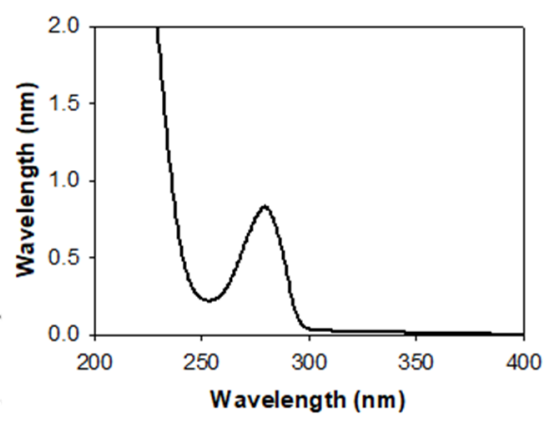

Figure 1. (a) Synthesis and chemical structures of hyaluronic acid (HA)-catechol. (b) ${ }^{1} \mathrm{H}$ NMR and (c) UV-Vis spectra of HA-catechol.

\section{General Properties of Hyaluronic Acid-Catechol}

\subsection{Biocompatibility}

High levels of HA are present in tissues and cartilage, particularly in those of the musculoskeletal system. In addition, HA is widely used in medical applications mainly due to its biocompatibility. The conjugation of molecules to HA does not significantly affect its biocompatibility. For instance, injectable tyramine-conjugated HA hydrogels prepared by the oxidative crosslinking of phenolic groups maintain high cell viability (>95\%) of human mesenchymal stem cells (hMSCs) for up to 14 days [87]. In addition, the viability of MSCs in an HA hydrogel crosslinked with polyethylene glycol (HA-PEG gel) was 100\% when $10^{6}$ cells $\mathrm{mL}^{-1}$ of MSCs were treated with the hydrogel for three days [88].

Similarly, HA-catechol is also non-cytotoxic and biocompatible. Treatment of cells at a density of $1.0 \times 10^{6}$ cells $/ 100 \mu \mathrm{L}$ with a pre-gelation $\mathrm{HA}$-catechol solution preserves cell viability $(\sim 100 \%)$ [46]. Treatment with extracts of HA-catechol hydrogels maintains $\sim 83 \%$ viability in L929 cells compared to that obtained using fresh media. In addition, the viability of human hepatocytes (hHEPs) encapsulated in HA-catechol hydrogels prepared by the addition of $\mathrm{NaIO}_{4}$ was $\sim 70.9 \%$, which is far higher than that observed using HAmethacrylate hydrogels $(\sim 52.2 \%)$ on day 14 of treatment $[46,89]$. Furthermore, HA-catechol hydrogels incorporated with basic fibroblast growth factor exhibit improved hHEPs cell viability to $\sim 81.4 \%$ after 14 days [37]. The viability of human neural stem cells (hNSCs) in an $\mathrm{HA}$-catechol hydrogel after seven days was approximately $70 \%$, which is two-fold that observed using an HA-methacrylate hydrogel (less than 30\%).

\subsection{Tissue Adhesive Properties}

HA has anti-adhesive properties; therefore, HA-based physical barriers have been developed to prevent post-surgical adhesion. However, the conjugation of catechol groups 
to HA significantly increases the adhesiveness of HA-catechol to tissues. As mentioned, the oxidized catechol groups (i.e., catechol quinone) can covalently react with the amine or thiol groups that are abundantly found in native tissues, including proteoglycan structures, resulting in superior tissue adhesive properties. The tissue adhesive properties of HAcatechol are commonly measured with a lap shear test using animal skin, such as chicken or porcine skin (Figure 2a). In addition, post-crosslinking of HA-catechol adhesives is carried out prior to its use on skin or dermal tissues to improve tissues' adhesion properties in general. The adhesive stress withstood by joint chicken skins in the presence of HAcatechol hydrogels is approximately $10 \mathrm{kPa}$, which is far greater than that bore when using methacrylated HA hydrogels (Figure 2b) [52]. In addition, tissue adhesive properties are improved by the addition of an oxidative intermolecular crosslink agent $\left(\mathrm{NaIO}_{4}\right)$ and by an increase of DS in HA-catechol. The maximum adhesive strength is $90.0 \pm 6.7 \mathrm{kPa}$ when using HA-catechol with high DS (0.45) at a molar ratio of 1:2 (catechol/ $/ \mathrm{NaIO}_{4}$ ). Moreover, the addition of $\mathrm{Fe}^{3+}$ ions to the hydrogels increases the adhesive stress of HAcatechol. The detachment stress of hydrogels containing HA-catechol $/ \mathrm{Fe}^{3+}$ complexes is $14.8 \pm 0.9 \mathrm{kPa}$, while that of an HA-catechol solution is $0.9 \pm 0.5 \mathrm{kPa}$, measured using mouse subcutaneous tissues [47].

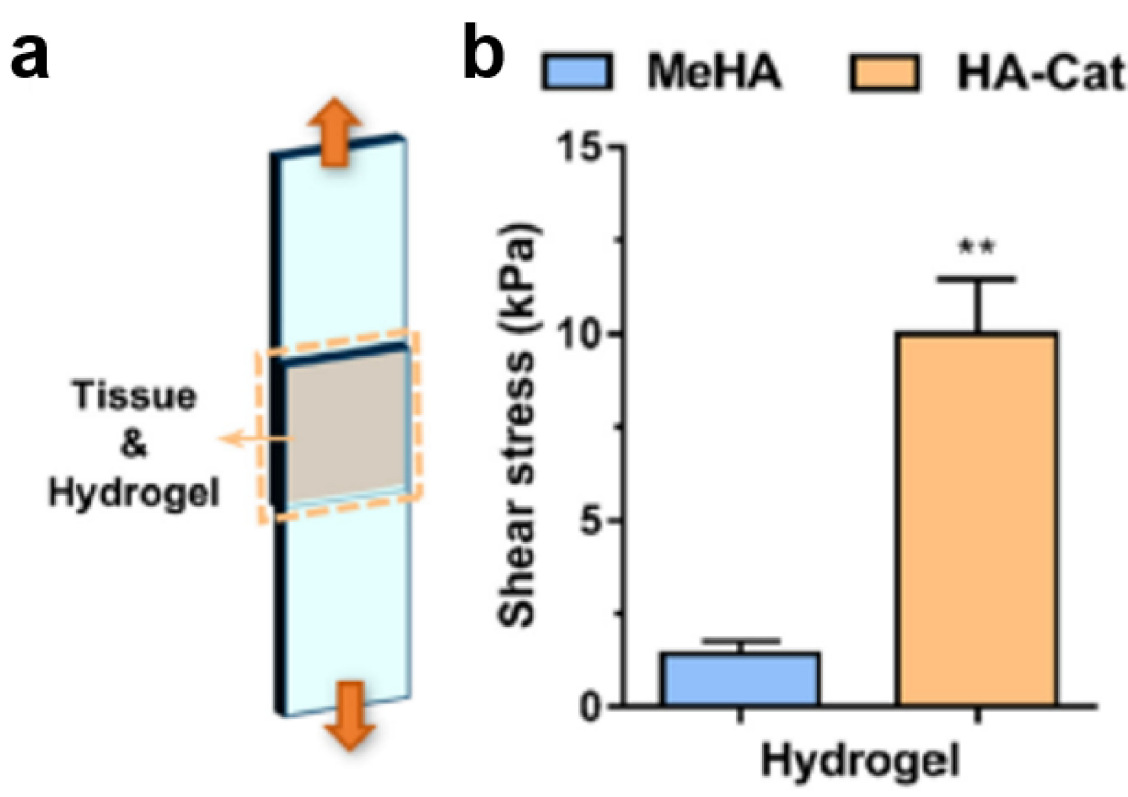

Figure 2. (a) Schematic illustration of a lap shear tissue adhesion test. (b) Average adhesive stress $(\mathrm{kPa})$ of methacrylated HA (MeHA) and HA-catechol (HA-Cat) hydrogels $\left({ }^{* *} p<0.01\right)$. Reprinted with permission from [52]. Copyright (C) 2019 Elsevier.

HA-catechol-based composite materials also show excellent adhesive properties. For instance, HA-catechol and Pluronic F127 (16 wt \%) composite hydrogels show excellent stability with approximately 10-fold greater adhesive strength $(\sim 7.2 \mathrm{kPa})$ than HA-catechol alone ( 1.7 kPa) [48]. HA-catechol/PVA (Polyvinyl alcohol) hydrogel composite films can be used as mucoadhesive films for the treatment of oral candidiasis [49]. HA-catechol/PVA hydrogels have a high detachment force of approximately $0.23 \mathrm{~N}$, which was measured using a bovine buccal membrane. HA-catechol/PLL (poly-L-lysine) hydrogels enzymatically crosslinked with horseradish peroxidase (HRP) with $\mathrm{H}_{2} \mathrm{O}_{2}$ showed a significant improvement in adhesive strength, from $20.8 \mathrm{kPa}$ to $33.8 \mathrm{kPa}$ [39]. Therefore, HA-catechol is useful for long-term tissue adhesion and may have great potential for use in biomedical applications. Furthermore, the tissue adhesiveness of HA-catechol may prevent the malposition or movement of the HA-based materials on the targeted tissue surfaces. 


\subsection{Catechol-Involving Reactions}

The catechol groups in HA backbones can undergo chemical and physical reactions during the manufacture of formulations (i.e., hydrogels, thin films, and nanoparticles) and help them adhere to various substrates (i.e., tissues, metal/metal oxide, polymer surfaces). For example, hydrogels can be prepared by the covalent and/or non-covalent crosslinking of polymers via catechol-involving reactions (Figure 3) [37,39,43,46-48,50-58]. Catechol groups in basic $\mathrm{pH}$ conditions transform into catechol quinone, which is highly reactive towards amines, thiols, and other catechol groups because of their pKa values (pKa1: 9.25; pKa2: 13.0) [90]. Oxidants (e.g., sodium periodate, $\mathrm{NaIO}_{4}$ ) are used to achieve the rapid gelling of HA-catechol hydrogels [37,46,51-54]. HA-catechol achieves a crosslinked gel state with instantaneous solidification upon the addition of $\mathrm{NaIO}_{4}$. The optimized stoichiometric ratio of $\mathrm{NaIO}_{4}$ / catechol for the preparation of HA-catechol hydrogels is 1.5:1, which results in rapid gelation within $10 \mathrm{~s}$ [37]. Additionally, oxidoreductase has previously been used to prepare HA-catechol hydrogels [39,57]. When $\mathrm{H}_{2} \mathrm{O}_{2}(0.01 \% v / v)$ and HRP $(0.05 \mathrm{mg} / \mathrm{mL}$ and $0.1 \mathrm{mg} / \mathrm{mL})$ were added to an HA-catechol solution, the gelation time significantly decreased to $12.5 \mathrm{~s}$ for $0.05 \mathrm{mg} / \mathrm{mL}$ of HRP and to $5.2 \mathrm{~s}$ for $0.1 \mathrm{mg} / \mathrm{mL}$ of HRP [57]. In addition to covalent crosslinking, HA-catechol hydrogels are prepared by non-covalent reactions of polymers. In general, the catechol groups can bind to various molecules and substrates by hydrogen bonds, $\pi-\pi$ stacking, cation $-\pi$ interactions, and metal coordination. In particular, catechol groups strongly bind to $\mathrm{Fe}^{3+}$ ions, as previously reported [91-96]. The rapid gelling of HA-catechol hydrogels is achieved by the addition of $\mathrm{Fe}^{3+}$ ions to a solution of HA-catechol $[47,59]$. The elastic modulus value of $\mathrm{Fe}^{3+}$ ionmediated HA-catechol hydrogels at a concentration of $10 \mathrm{mM} \mathrm{FeCl}_{3}$ was $\sim 4.6 \mathrm{kPa}$, which is far higher than that of the HA-catechol solution ( 1.7 Pa) [47]. In addition, the gelation time could be controlled by changing the $\mathrm{Fe}^{3+}$-catechol stoichiometric ratio. For instance, the gelation time decreased by increasing the $\mathrm{Fe}^{3+}$-catechol ratio from $1: 1\left(6.5 \mathrm{mM} \mathrm{Fe}^{3+}\right.$ and catechol) to 1:3 [59]. Therefore, catechol-involving reactions of HA-catechol can be utilized to prepare injectable hydrogels, drug delivery depots, and tissue engineering scaffolds.

a

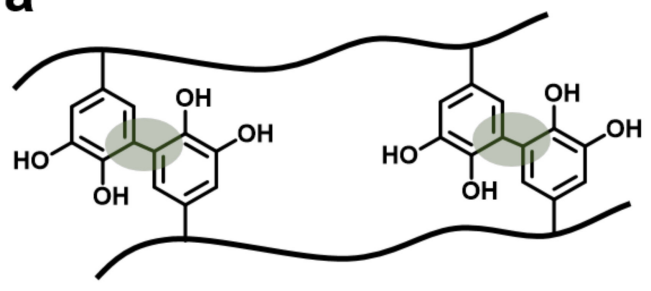

C

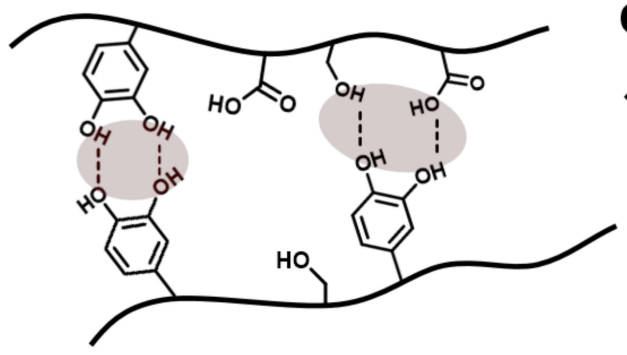

b

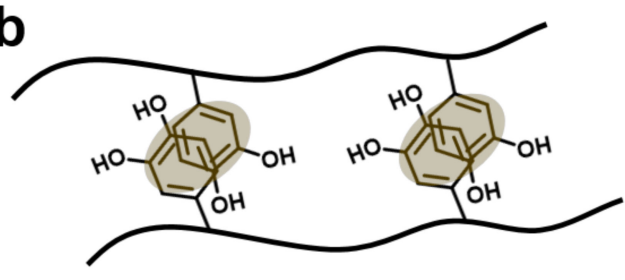

d

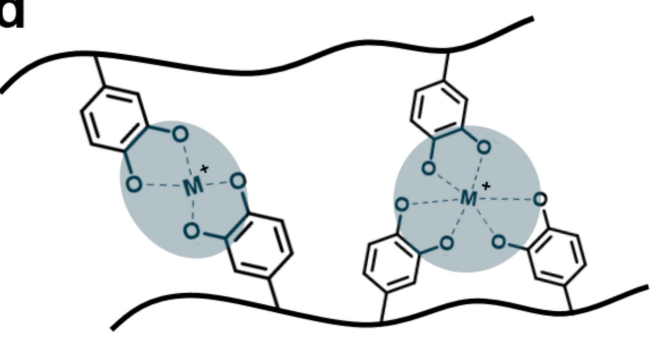

Figure 3. Schematic illustration of catechol-involving reactions of HA-catechol: (a) covalent bonds, (b) $\pi-\pi$ stacking, (c) hydrogen bonds, and (d) metal coordination.

\section{Biomedical Applications}

HA-catechol is widely used in biomedical applications owing to its biocompatibility, adhesiveness, and anti-inflammatory properties. In this section, we describe the various 
biomedical uses of HA-catechol, focusing on its physicochemical properties and catecholinvolving chemical reactions with tissues and/or biomacromolecules.

\subsection{Antifouling Materials}

HA is a representative antifouling material mainly due to its hydrophilicity and its unique moisture retention and lubrication abilities. The catechol moiety of HA-catechol can form a thin film on substrates (Figure 4a). These HA-catechol coatings on Au surfaces enhance hydrophilicity ( $11.9^{\circ}$ of water contact angle) compared to that measured on bare Au surfaces $\left(81.6^{\circ}\right)$ [40]. In addition, HA-catechol-coated Au substrates have extremely low protein-adsorption levels $\left(<5 \mathrm{ng} / \mathrm{cm}^{2}\right)$ for single proteins (i.e., bovine serum albumin, lysozymes, and $\beta$-lactoglobulin). Polyimide (PI), Au, poly(methyl methacrylate) (PMMA), polytetrafluoroethylene (PTFE), and polyurethane (PU) are coated with HA-catechol to prepare antifouling substrates [60]. All substrates coated with HA-catechol exhibit improved hydrophilicity of the substrates (less than $50^{\circ}$ of water contact angle) compared to the unmodified substrates, as shown in Figure $4 \mathrm{~b}$. The adsorption of bovine serum albumin on HA-catechol-coated substrates was dramatically reduced to $22-46 \%$ compared to that on unmodified surfaces (Figure 4c). Therefore, HA-catechol is an excellent coating agent for the antifouling treatment of biomedical devices.

a
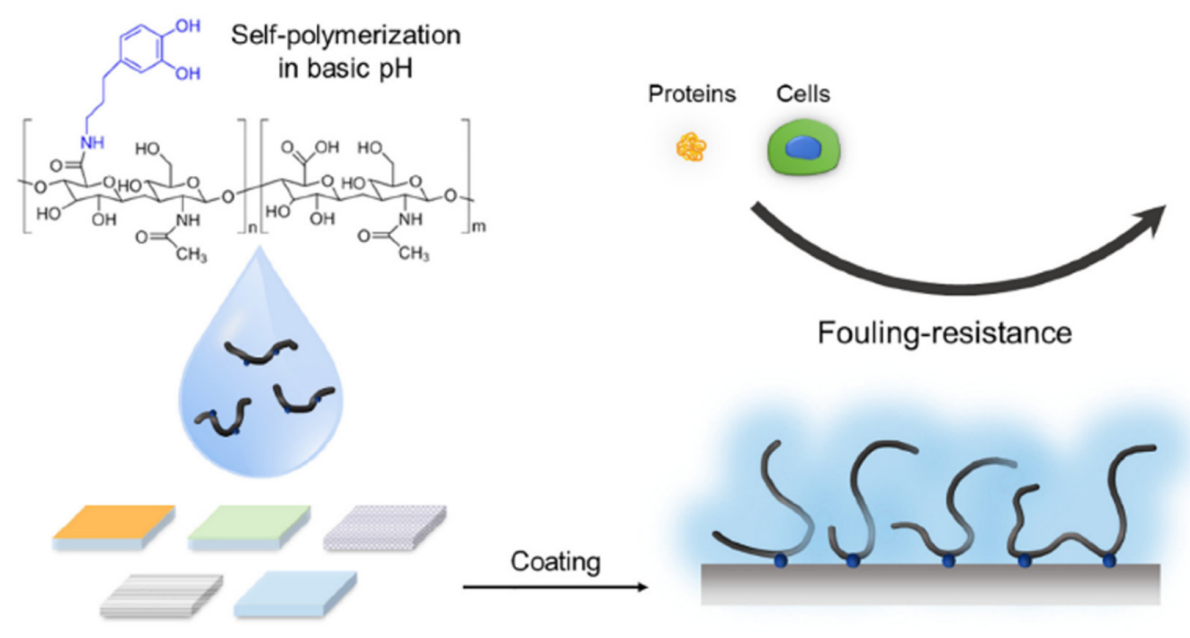

Various implantable biomaterials

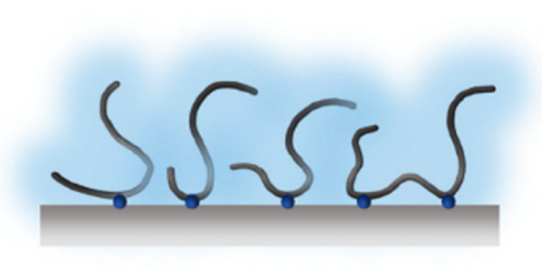

Anti-biofouling surfaces

b

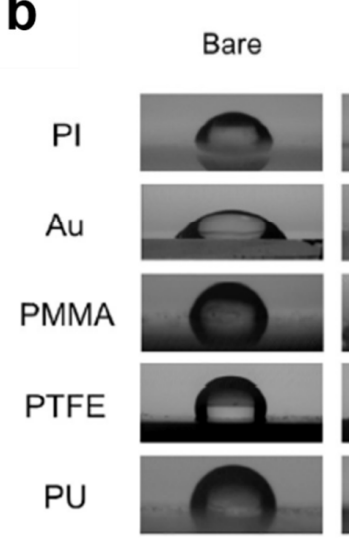

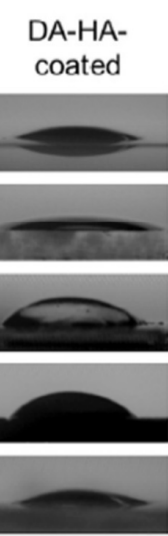

C

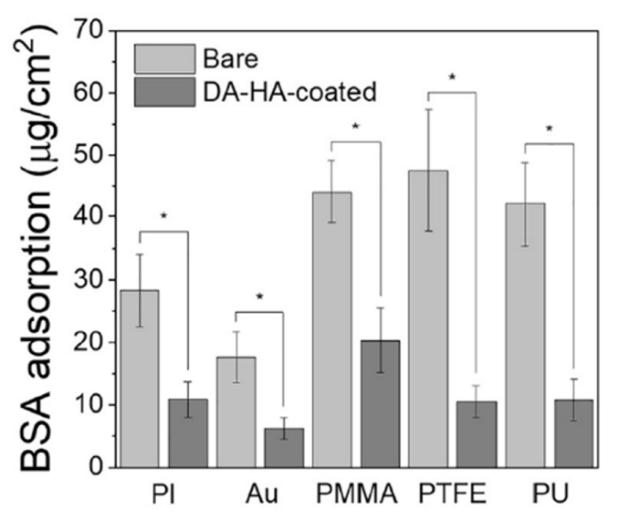

Figure 4. (a) Schematic illustration of HA-catechol (dopamine-conjugated HA: DA-HA) coating on various substrates (i.e., PI (polyimide), gold (Au), poly(methyl methacrylate) (PMMA), polytetrafluoroethylene (PTFE), and polyurethane (PU)) for antifouling applications. (b) Water contact angle measurements of various substrates before and after HA-catechol coating. (c) BSA (bovine serum albumin) adsorption $\left(\mu \mathrm{g} / \mathrm{cm}^{2}\right.$ ) on bare and HA-catechol-coated surfaces after treatment with a BSA solution $(1 \mathrm{mg} / \mathrm{mL})$ at $37^{\circ} \mathrm{C}$ for $6 \mathrm{~h}\left({ }^{*} p<0.05\right)$. Reproduced with permission from [60]. Copyright (C) 2020 Elsevier. 


\subsection{Wound-Healing Materials}

HA-catechol materials have been investigated as wound-healing materials because reactive oxygen species can be scavenged by catechol groups. The incorporation of antiinflammatory drugs into HA-catechol hydrogels significantly improves wound closure and healing. For instance, arginine derivatives have been incorporated into HA-catechol hydrogels, as shown in Figure 5a [62]. To confirm the antioxidant properties, 2,2-diphenyl1-picrylhydrazyl (DPPH) and hydroxyl radical $(\mathrm{OH})$ scavenging experiments are generally used. An arginine/HA-catechol composite hydrogel showed strong antioxidant activity with maximum $\mathrm{OH}$ and DPPH free-radical scavenging rates of $41.1 \%$ and $67.4 \%$, respectively. In addition, complete wound closure and healing could be achieved using these hydrogels after 21 days (Figure 5b). HA-catechol conjugated with chitosan is also used as a wound-healing material [57]. Wound healing can be improved by increasing the concentrations of $\mathrm{H}_{2} \mathrm{O}_{2}$ and HRP. HA-catechol/chitosan composite hydrogels with the addition of $\mathrm{H}_{2} \mathrm{O}_{2}(0.05 \%, v / v)$ and $\mathrm{HRP}(0.1 \mathrm{mg} / \mathrm{mL})$ showed complete wound healing nine days post-surgery, which depicts a wound closure effect similar to that obtained using surgical suturing, indicating that these hydrogels could replace surgical sutures to achieve wound closure. In addition, a mild acute inflammatory response was observed for six days after the implantation of HA-catechol/chitosan hydrogels, and inflammation receded on the ninth day after surgery. This is similar to the biocompatibility of surgical sutures and enzymatically (HRP) crosslinked hydrogels.

\section{a}
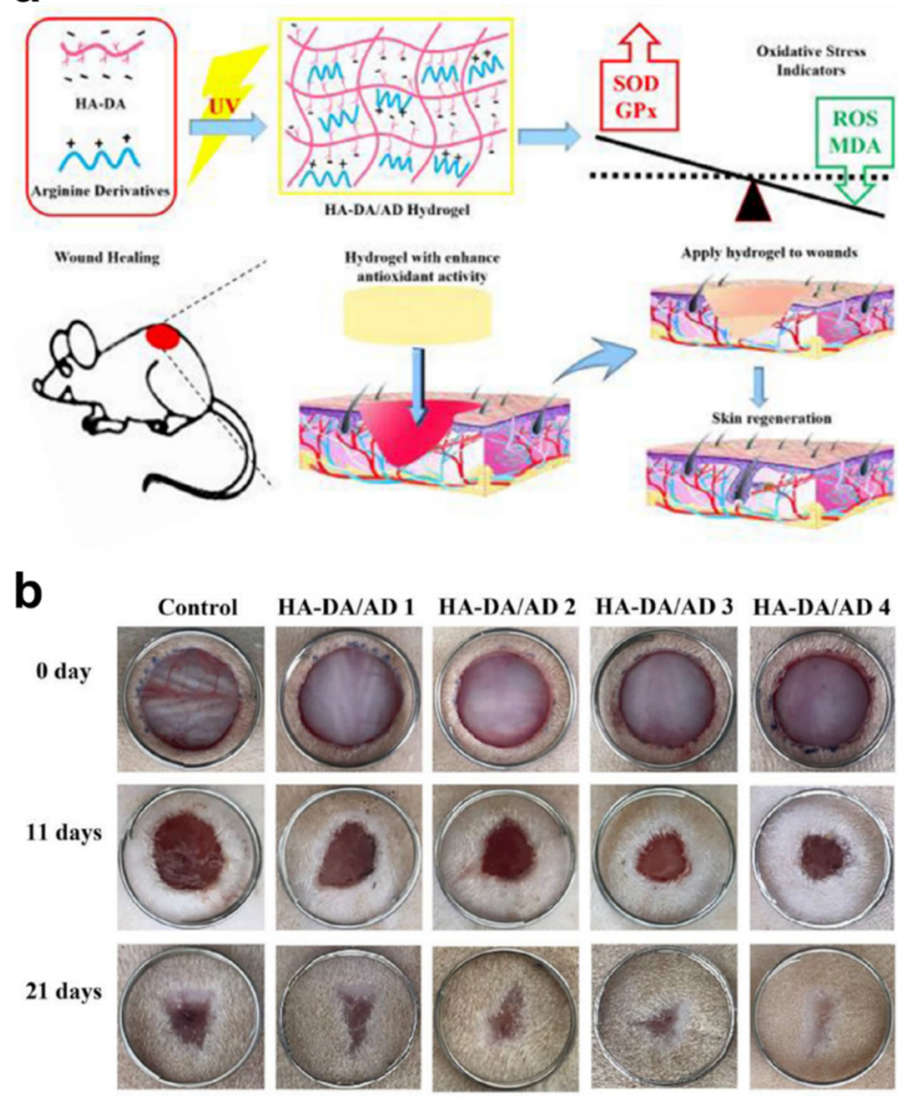

Figure 5. (a) Schematic illustration of methacrylated HA-catechol (HA-DA) and arginine derivatives (AD) composite hydrogels for wound healing. (b) Photographic images of rat skin wounds after treatments of HA-DA/AD hydrogels with various pore sizes (14.18 $\pm 1.54 \mu \mathrm{m}$ for HA-DA/AD1, $13.09 \pm 0.79 \mu \mathrm{m}$ for HA-DA/AD2, $11.08 \pm 1.16 \mu \mathrm{m}$ for HA-DA/AD3, and $9.07 \pm 2.17 \mu \mathrm{m}$ for HA-DA/AD hydrogels). Treatment with PBS was used as a control. Reproduced with permission from [62]. Copyright (C) 2019 Elsevier. 


\subsection{Drug/Gene Delivery Carriers}

A challenge in cancer treatment is targeting anticancer drug delivery to increase the efficiency of drugs. Because HA interacts with CD44, overexpressed in cancer cells, HA-based hydrogels as drug/gene delivery carriers have been developed for anticancer drug therapy. The catechol groups in HA can act as coating and crosslinking moieties to achieve sustained drug release. For instance, HA-catechol/chitosan composite nanoparticles containing the anticancer drug doxorubicin (DOX), with a high loading capacity of $250 \mu \mathrm{g} / \mathrm{mg}$, exhibited a controlled release of DOX, in comparison to the administration of free DOX [63]. In addition, the nanoparticles showed mucoadhesive properties; over $60 \%$ of the nanoparticles remained on the buccal mucosa after washing with artificial saliva, while only $10 \%$ remained when dextran was used as a control. In addition, these nanoparticles showed enhanced cellular uptake and accumulation in HN22 cells. Furthermore, treatment using DOX nanoparticles led to extensive apoptosis (22\% of the apoptotic rate), which was higher than that observed using free DOX (16\%). HA-catechol hydrogels containing amine-functionalized graphene oxide (GO) are prepared by covalent reactions involving the catechol groups of HA and the amine groups of GO [53]. DOX is noncovalently bound to GO in hydrogels by hydrophobic interactions and $\pi-\pi$ stacking. In addition, controlled DOX release profiles have been obtained using HA-catechol/GO hydrogels. HA-catechol hollow nanoparticles have also been developed to deliver anticancer drugs. Silica nanoparticles are coated with HA-catechol, and the inner silica particles are removed to fabricate hollow HA-catechol particles to load anticancer drugs, such as DOX [65]. The hollow HA-catechol particles showed drug-loading efficiency ( 20 wt $\%)$ with different drug-release profiles between $\mathrm{pH} 5.5$ and 7.4. At $\mathrm{pH} 5.5,67 \%$ of DOX was released from the particles within $8 \mathrm{~h}$, while $25 \%$ of DOX release occurred at $\mathrm{pH} 7.4$ after $60 \mathrm{~h}$. Considering the $\mathrm{pH}$ of the physiological conditions and the cancer microenvironment, these particles can effectively lead to cancer cell death after $\mathrm{pH}$-triggered DOX release. In addition, HA-catechol-coated Au nanorods have been fabricated for cancer therapy via the interaction of catechol and Au [66]. DOX was covalently conjugated to HA-catechol, which has an acid-labile hydrazone linkage. The release of DOX from the HA-catecholcoated Au nanorods was controlled by two stimuli, namely, $\mathrm{pH}$ and NIR (near-infrared) light, and was found to be successful in inhibiting the growth of breast cancer cells.

HA-catechol-based gene delivery has been performed using calcium phosphate (CaP)containing plasmid DNA or siRNA [45]. HA-catechol has been used as a binder for $\mathrm{CaP}$ and cancer-targeting materials. Stabilized $\mathrm{CaP} /$ siRNA/HA-catechol nanoparticles are prepared by the simple mixing of solutions and involve specific interactions between calcium and catechol. The nanoparticles deliver siRNA to cancer cells via endocytosis. In the HT29-luc tumor xenograft model, the nanoparticles showed no sign of hepatic toxicity after systemic administration and successfully inhibited cancer growth through the gene silencing effect of siRNA. In addition, CAP nanoparticles stabilized by HA-catechol have been designed to enhance the transfection of hMSCs in a gene delivery system, as shown in Figure 6 [41]. The CAP nanoparticles stabilized by HA-catechol showed efficient gene delivery of both pBMP-2 as a plasmid DNA and mir148b as a microRNA to stem cells via CD44-specific receptor-mediated endocytosis.

\subsection{Tissue Engineering Scaffolds}

In general, chemical modification of HA-based materials is required for tissue engineering, mainly due to the poor mechanical properties of unmodified HA under physiological conditions. The conjugation of catechol to HA increases its mechanical properties with excellent stability against hyaluronidase. HA-catechol is especially useful to promote osteogenesis and angiogenesis. Vascular endothelial growth factor (VEGF) was previously immobilized on a Ti surface using HA-catechol [50]. The VEGF-immobilized Ti substrate $\left(60 \mathrm{ng} / \mathrm{cm}^{2}\right)$ sustained osteoblast proliferation $\left(70,000\right.$ osteoblasts $\left./ \mathrm{cm}^{2}\right)$ after seven days of incubation. In addition, the alkaline phosphatase activity $(0.7 \mu \mathrm{M} / \mathrm{mg})$ of VEGF-immobilized Ti substrate was greater than that of bare Ti surfaces $(0.3 \mu \mathrm{M} / \mathrm{mg})$. 
Moreover, the VEGF-immobilized Ti substrate using HA-catechol not only allowed osteogenesis for bone formation, but also inhibited bacterial adhesion. In addition, HA-catechol can form thin films with chitosan on a Ti-Nb-Zr alloy (TNZ) [67]. HA-catechol- and chitosan-coated TNZ surfaces improve the proliferation of osteoblast cells, with approximately 35,000 osteoblasts $/ \mathrm{cm}^{2}$ after seven days, which is comparable with the proliferation levels achieved with bare TNZ (30,000 osteoblasts $\left./ \mathrm{cm}^{2}\right)$. The modification of Ti surfaces with HA-catechol can be used to enhance osteogenesis and angiogenesis. HA-catechol has been used for salivary gland tissue engineering (Figure 7). A polycarbonate (PC) membrane coated with HA-catechol showed enhanced adhesion of embryonic submandibular glands (eSMGs) (5.2-fold increase of for the number of adherent eSMGs) compared to both bare and HA-coated membranes [44]. In addition, branching morphogenesis, including average bud counts, was enhanced by HA-catechol coatings mimicking an HA-rich environment. HA-catechol composite hydrogels with carbon nanotubes (CNTs) and/or polypyrrole (PPy) have been developed for hNSC engineering [54]. The catechol groups bound to CNTs via hydrophobic and $\pi-\pi$ interactions promote the polymerization of and. CNT and/or PPy in hydrogels contribute to the improvement of electroconductivity to promote the differentiation of human fetal NSCs and human induced pluripotent stem cell-derived neural progenitor cells. In addition, upregulated calcium channel expression and activation of depolarization have been observed in human stem cells using HA-catechol/CNT hydrogels, and intracellular calcium influx is also enhanced by the stimulation of electrical signals. Therefore, HA-catechol can be used in various tissue-engineering applications, including those involving bone, cartilage, salivary gland, and neural tissue regeneration.

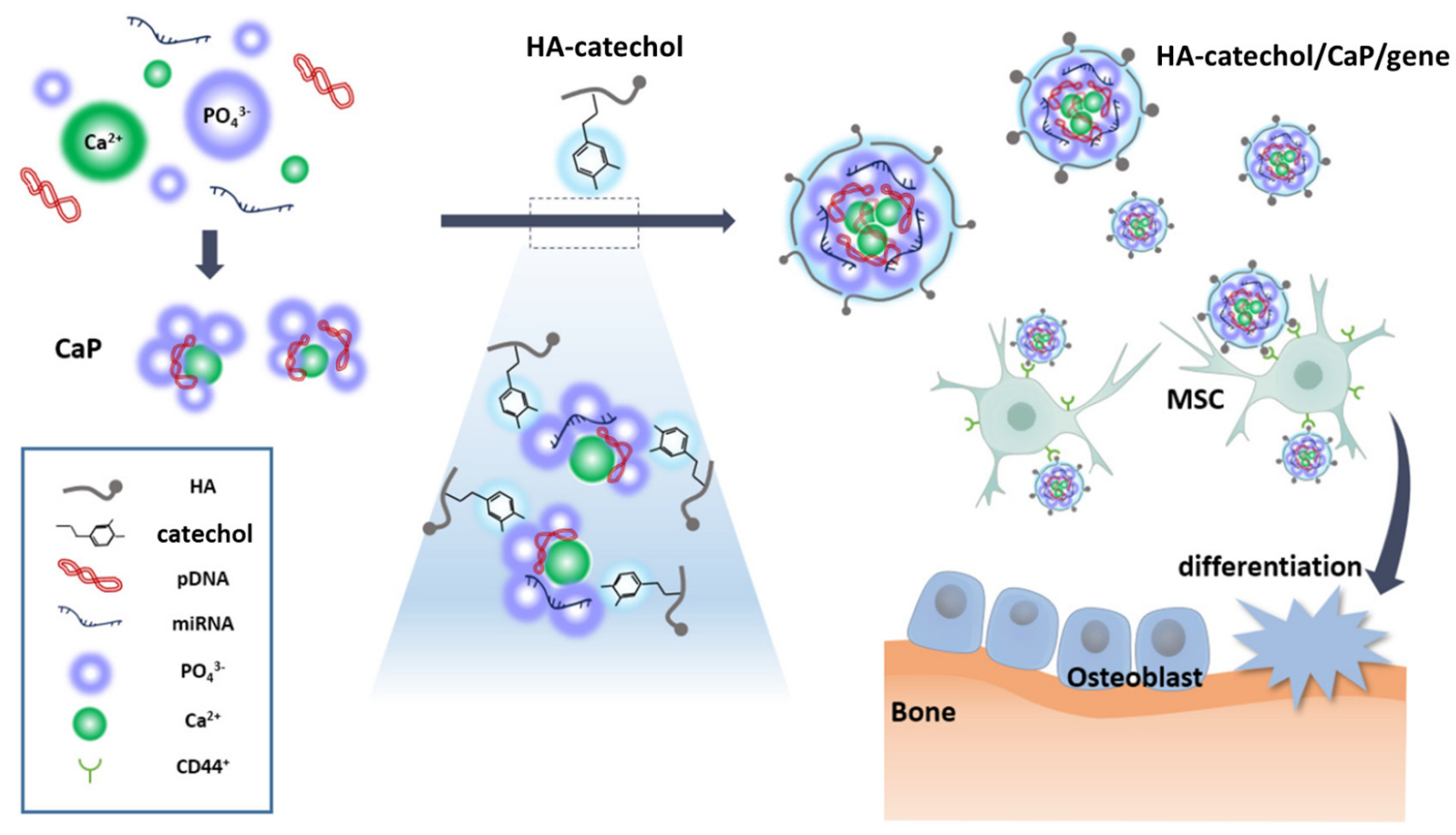

Figure 6. Schematic representation of an HA-catechol/CaP-based gene delivery system. Reproduced from [41] with permission from MDPI, copyright 2019. 

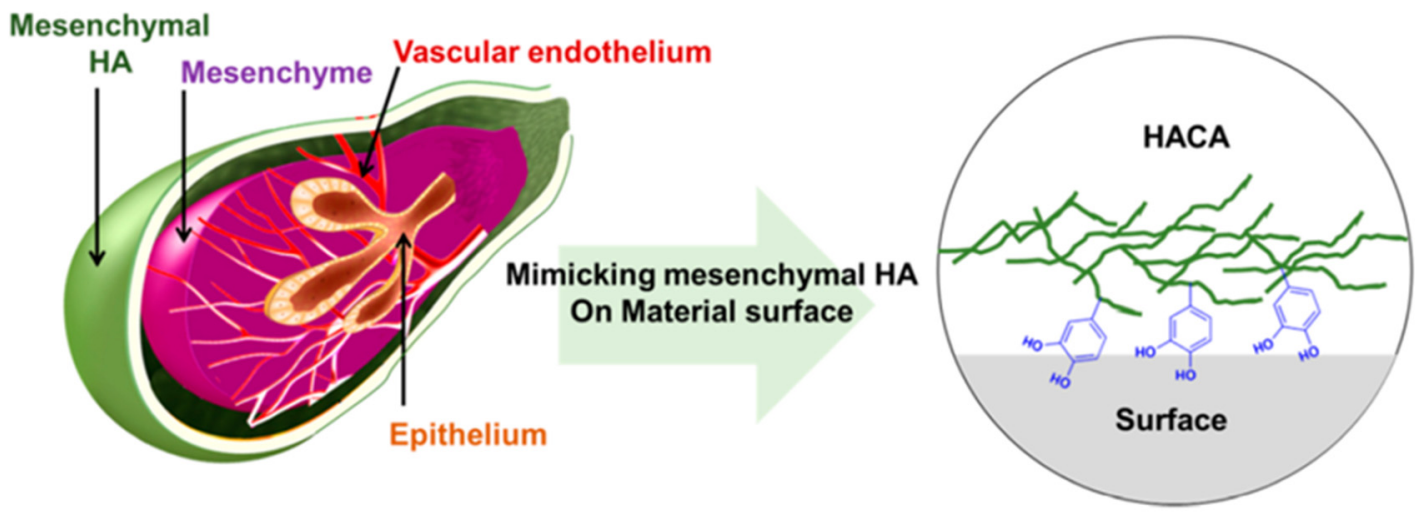

Figure 7. Schematic illustration of mesenchymal HA-mimicking HA-catechol platform for salivary gland tissue engineering. Reprinted with permission from [44]. Copyright (C) 2020 American Chemical Society.

\section{Conclusions}

In this review, we have described the synthetic and characteristic methodologies, general properties, and various biomedical applications of HA-catechol, including antifouling, tissue adhesives, wound healing, drug/gene delivery, and tissue engineering. Catechol conjugation onto HA backbones significantly enhances HA mechanical and tissue adhesive properties due to catechol-involving reactions, allowing various biomedical applications. In addition, the intrinsic properties of $\mathrm{HA}$, such as biocompatibility and biodegradability, are still conserved after the conjugation of the catechol groups. We expect that HA-catechol will be exploited as an adhesive and biocompatible material in many clinical settings, opening the doors to translational researches to enhance therapies.

Author Contributions: Conceptualization, J.K., C.L., J.H.R.; writing—original draft preparation, J.K., C.L., J.H.R.; writing—review and editing, J.K., J.H.R.; supervision, J.H.R. All authors have read and agreed to the published version of the manuscript.

Funding: This research was supported by Wonkwang University in 2018.

Institutional Review Board Statement: Not applicable.

Informed Consent Statement: Not applicable.

Data Availability Statement: Data sharing not applicable.

Conflicts of Interest: The authors declare no conflict of interest.

\section{References}

1. Fraser, J.R.E.; Laurent, T.C.; Laurent, U.B.G. Hyaluronan: Its nature, distribution, functions and turnover. J. Intern. Med. 1997, 242, 27-33. [CrossRef] [PubMed]

2. Highley, C.B.; Prestwich, G.D.; Burdick, J.A. Recent advances in hyaluronic acid hydrogels for biomedical applications. Curr. Opin. Biotechnol. 2016, 40, 35-40. [CrossRef] [PubMed]

3. Tiwari, S.; Bahadur, P. Modified hyaluronic acid based materials for biomedical applications. Int. J. Biol. Macromol. 2019, 121, 556-571. [CrossRef] [PubMed]

4. Kim, S.; Moon, M.J.; Poilil Surendran, S.; Jeong, Y.Y. Biomedical applications of hyaluronic acid-based nanomaterials in hyperthermic cancer therapy. Pharmaceutics 2019, 11, 306. [CrossRef] [PubMed]

5. Kogan, G.; Soltes, L.; Stern, R.; Gemeiner, P. Hyaluronic acid: A natural biopolymer with a broad range of biomedical and industrial applications. Biotechnol. Lett. 2007, 29, 17-25. [CrossRef]

6. Price, R.D.; Berry, M.G.; Navsaria, H.A. Hyaluronic acid: The scientific and clinical evidence. J. Plast. Reconstr. Aesthet. Surg. 2007, 60, 1110-1119. [CrossRef]

7. Fakhari, A.; Berkland, C. Applications and emerging trends of hyaluronic acid in tissue engineering, as a dermal filler and in osteoarthritis treatment. Acta Biomater. 2013, 9, 7081-7092. [CrossRef]

8. Monheit, G.D.; Coleman, K.M. Hyaluronic acid fillers. Dermatol. Ther. 2006, 19, 141-150. [CrossRef]

9. Yeo, Y.; Highley, C.B.; Bellas, E.; Ito, T.; Marini, R.; Langer, R.; Kohane, D.S. In Situ cross-linkable hyaluronic acid hydrogels prevent post-operative abdominal adhesions in a rabbit model. Biomaterials 2006, 27, 4698-4705. [CrossRef] 
10. Luo, Y.; Kirker, K.R.; Prestwich, G.D. Cross-linked hyaluronic acid hydrogel films new biomaterials for drug delivery. J. Control. Release 2000, 69, 169-184. [CrossRef]

11. Collins, M.N.; Birkinshaw, C. Hyaluronic acid based scaffolds for tissue engineering-A review. Carbohydr. Polym. 2013, 92, 1262-1279. [CrossRef] [PubMed]

12. Yoo, H.S.; Lee, E.A.; Yoon, J.J.; Park, T.G. Hyaluronic acid modified biodegradable scaffolds for cartilage tissue engineering. Biomaterials 2005, 26, 1925-1933. [CrossRef] [PubMed]

13. Burdick, J.A.; Prestwich, G.D. Hyaluronic acid hydrogels for biomedical applications. Adv. Mater. 2011, 23, H41-H56. [CrossRef]

14. Dicker, K.T.; Gurski, L.A.; Pradhan-Bhatt, S.; Witt, R.L.; Farach-Carson, M.C.; Jia, X. Hyaluronan: A simple polysaccharide with diverse biological functions. Acta Biomater. 2014, 10, 1558-1570. [CrossRef] [PubMed]

15. Swann, D.A.; Radin, E.L.; Nazimiec, M.; Weisser, P.A.; Curran, N.; Lewinnek, G. Role of hyaluronic acid in joint lubrication. Ann. Rheum. Dis. 1974, 33, 318-326. [CrossRef] [PubMed]

16. Necas, J.; Bartosikova, L.; Brauner, P.; Kolar, J. Hyaluronic acid (hyaluronan): A review. Vet. Med. 2008, 53, 397-411. [CrossRef]

17. Meyer, K. The biological significance of hyaluronic acid and hyaluronidase. Phys. Rev. 1947, 27, 335-359. [CrossRef]

18. Waite, J.H.; Andersen, N.H.; Jewhurst, S.; Sun, C. Mussel Adhesion: Finding the Tricks Worth Mimicking. J. Adhes. 2005, 81, 297-317. [CrossRef]

19. Waite, J.H.; Tanzer, M.L. Polyphenolic substance of Mytilus edulis: Novel adhesive containing L-dopa and hydroxyproline. Science 1981, 212, 1038-1040. [CrossRef]

20. Silverman, H.G.; Roberto, F.F. Understanding marine mussel adhesion. Mar. Biotechnol. 2007, 9, 661-681. [CrossRef]

21. Waite, J.H. Polyphosphoprotein from the adhesive pads of Mytilus edulis. Biochemistry 2001, 40, 2887-2893. [CrossRef] [PubMed]

22. Yu, M.; Hwang, J.; Deming, T.J. Role of L-3,4-dihydroxyphenylalanine in mussel adhesive proteins. J. Am. Chem. Soc. 1999, 121, 5825-5826. [CrossRef]

23. Lee, H.; Dellatore, S.M.; Miller, W.M.; Messersmith, P.B. Mussel-inspired surface chemistry for multifunctional coatings. Science 2007, 318, 426-430. [CrossRef] [PubMed]

24. Ryu, J.H.; Messersmith, P.B.; Lee, H. Polydopamine surface chemistry: A decade of discovery. ACS Appl. Mater. Interfaces 2018, 10, 7523-7540. [CrossRef] [PubMed]

25. Li, L.; Zeng, H. Marine mussel adhesion and bio-inspired wet adhesives. Biotribology 2016, 5, 44-51. [CrossRef]

26. Park, S.; Kim, S.; Jho, Y.; Hwang, D.S. Cation-pi interactions and their contribution to mussel underwater adhesion studied using a surface forces apparatus: A mini-review. Langmuir ACS J. Surf. Colloids 2019, 35, 16002-16012. [CrossRef]

27. Faure, E.; Falentin-Daudré, C.; Jérôme, C.; Lyskawa, J.; Fournier, D.; Woisel, P.; Detrembleur, C. Catechols as versatile platforms in polymer chemistry. Prog. Polym. Sci. 2013, 38, 236-270. [CrossRef]

28. Zhang, H.; Zhao, T.; Newland, B.; Liu, W.; Wang, W.; Wang, W. Catechol functionalized hyperbranched polymers as biomedical materials. Prog. Polym. Sci. 2018, 78, 47-55. [CrossRef]

29. Lee, S.B.; Gonzalez-Cabezas, C.; Kim, K.M.; Kim, K.N.; Kuroda, K. Catechol-functionalized synthetic polymer as a dental adhesive to contaminated dentin surface for a composite restoration. Biomacromolecules 2015, 16, 2265-2275. [CrossRef]

30. Li, G.; Cheng, G.; Xue, H.; Chen, S.; Zhang, F.; Jiang, S. Ultra low fouling zwitterionic polymers with a biomimetic adhesive group. Biomaterials 2008, 29, 4592-4597. [CrossRef]

31. Zhang, W.; Wang, R.; Sun, Z.; Zhu, X.; Zhao, Q.; Zhang, T.; Cholewinski, A.; Yang, F.; Zhao, B.; Pinnaratip, R.; et al. Catecholfunctionalized hydrogels: Biomimetic design, adhesion mechanism, and biomedical applications. Chem. Soc. Rev. 2020, 49, 433-464. [CrossRef] [PubMed]

32. Ryu, J.H.; Hong, S.; Lee, H. Bio-inspired adhesive catechol-conjugated chitosan for biomedical applications: A mini review. Acta Biomater. 2015, 27, 101-115. [CrossRef] [PubMed]

33. Kim, K.; Ryu, J.H.; Lee, D.Y.; Lee, H. Bio-inspired catechol conjugation converts water-insoluble chitosan into a highly watersoluble, adhesive chitosan derivative for hydrogels and LbL assembly. Biomater. Sci. 2013, 1, 783-790. [CrossRef] [PubMed]

34. Ryu, J.H.; Lee, Y.; Kong, W.H.; Kim, T.G.; Park, T.G.; Lee, H. Catechol-functionalized chitosan/pluronic hydrogels for tissue adhesives and hemostatic materials. Biomacromolecules 2011, 12, 2653-2659. [CrossRef]

35. Ryu, J.H.; Kim, H.J.; Kim, K.; Yoon, G.; Wang, Y.; Choi, G.-S.; Lee, H.; Park, J.S. Multipurpose intraperitoneal adhesive patches. Adv. Funct. Mater. 2019, 29, 1900495. [CrossRef]

36. Shin, M.; Ryu, J.H.; Kim, K.; Kim, M.J.; Jo, S.; Lee, M.S.; Lee, D.Y.; Lee, H. Hemostatic swabs containing polydopamine-like catecholamine chitosan-catechol for normal and coagulopathic animal models. ACS Biomater. Sci. Eng. 2018, 4, $2314-2318$. [CrossRef]

37. Hong, S.; Yang, K.; Kang, B.; Lee, C.; Song, I.T.; Byun, E.; Park, K.I.; Cho, S.-W.; Lee, H. Hyaluronic acid-catechol: A biopolymer exhibiting a $\mathrm{pH}$-dependent adhesive or cohesive property for human neural stem cell engineering. Adv. Funct. Mater. 2013, 23, 1774-1780. [CrossRef]

38. Lih, E.; Choi, S.G.; Ahn, D.J.; Joung, Y.K.; Han, D.K. Optimal conjugation of catechol group onto hyaluronic acid in coronary stent substrate coating for the prevention of restenosis. J. Tissue Eng. 2016, 7, 1-11. [CrossRef]

39. Zhou, Y.; Kang, L.; Yue, Z.; Liu, X.; Wallace, G.G. Composite tissue adhesive containing catechol-modified hyaluronic acid and poly-L-lysine. ACS Appl. Bio Mater. 2020, 3, 628-638. [CrossRef]

40. Ye, H.; Xia, Y.; Liu, Z.; Huang, R.; Su, R.; Qi, W.; Wang, L.; He, Z. Dopamine-assisted deposition and zwitteration of hyaluronic acid for the nanoscale fabrication of low-fouling surfaces. J. Mater. Chem. B 2016, 4, 4084-4091. [CrossRef] 
41. Lee, J.E.; Yin, Y.; Lim, S.Y.; Kim, E.S.; Jung, J.; Kim, D.; Park, J.W.; Lee, M.S.; Jeong, J.H. Enhanced transfection of human mesenchymal stem cells using a hyaluronic acid/calcium phosphate hybrid gene delivery system. Polymers 2019, 11, 789. [CrossRef] [PubMed]

42. Neto, A.I.; Cibrao, A.C.; Correia, C.R.; Carvalho, R.R.; Luz, G.M.; Ferrer, G.G.; Botelho, G.; Picart, C.; Alves, N.M.; Mano, J.F. Nanostructured polymeric coatings based on chitosan and dopamine-modified hyaluronic acid for biomedical applications. Small 2014, 10, 2459-2469. [CrossRef] [PubMed]

43. Lee, J.; Chang, K.; Kim, S.; Gite, V.; Chung, H.; Sohn, D. Phase controllable hyaluronic acid hydrogel with iron(III) Ion-catechol induced dual cross-linking by utilizing the gap of gelation kinetics. Macromolecules 2016, 49, 7450-7459. [CrossRef]

44. Lee, S.W.; Ryu, J.H.; Do, M.J.; Namkoong, E.; Lee, H.; Park, K. NiCHE Platform: Nature-inspired catechol-conjugated hyaluronic acid environment platform for salivary gland tissue engineering. ACS Appl. Mater. Interfaces 2020, 12, 4285-4294. [CrossRef]

45. Lee, M.S.; Lee, J.E.; Byun, E.; Kim, N.W.; Lee, K.; Lee, H.; Sim, S.J.; Lee, D.S.; Jeong, J.H. Target-specific delivery of siRNA by stabilized calcium phosphate nanoparticles using dopa-hyaluronic acid conjugate. J. Control. Release 2014, 192, 122-130. [CrossRef]

46. Shin, J.; Lee, J.S.; Lee, C.; Park, H.-J.; Yang, K.; Jin, Y.; Ryu, J.H.; Hong, K.S.; Moon, S.-H.; Chung, H.-M.; et al. Tissue adhesive catechol-modified hyaluronic acid hydrogel for effective, minimally invasive cell therapy. Adv. Funct. Mater. 2015, 25, 3814-3824. [CrossRef]

47. Hong, S.H.; Ryu, J.H.; Lee, H. Effect of charge on In Vivo adhesion stability of catechol-conjugated polysaccharides. J. Ind. Eng. Chem. 2019, 79, 425-430. [CrossRef]

48. Lee, Y.; Chung, H.J.; Yeo, S.; Ahn, C.-H.; Lee, H.; Messersmith, P.B.; Park, T.G. Thermo-sensitive, injectable, and tissue adhesive sol-gel transition hyaluronic acid/pluronic composite hydrogels prepared from bio-inspired catechol-thiol reaction. Soft Matter 2010, 6, 977-983. [CrossRef]

49. Pornpitchanarong, C.; Rojanarata, T.; Opanasopit, P.; Ngawhirunpat, T.; Patrojanasophon, P. Clotrimazole nanosuspensionsloaded hyaluronic acid-catechol/polyvinyl alcohol mucoadhesive films for oral candidiasis treatment. J. Drug Deliv. Sci. Technol. 2020, 60, 101927. [CrossRef]

50. Hu, X.; Neoh, K.G.; Shi, Z.; Kang, E.T.; Poh, C.; Wang, W. An In Vitro assessment of titanium functionalized with polysaccharides conjugated with vascular endothelial growth factor for enhanced osseointegration and inhibition of bacterial adhesion. Biomaterials 2010, 31, 8854-8863. [CrossRef]

51. Park, H.J.; Jin, Y.; Shin, J.; Yang, K.; Lee, C.; Yang, H.S.; Cho, S.W. Catechol-functionalized hyaluronic acid hydrogels enhance angiogenesis and osteogenesis of human adipose-derived stem cells in critical tissue defects. Biomacromolecules 2016, 17, 1939-1948 [CrossRef] [PubMed]

52. Zhang, K.; Wei, Z.; Xu, X.; Feng, Q.; Xu, J.; Bian, L. Efficient catechol functionalization of biopolymeric hydrogels for effective multiscale bioadhesion. Mater. Sci. Eng. C Mater. Biol. Appl. 2019, 103, 109835. [CrossRef] [PubMed]

53. Byun, E.; Lee, H. Enhanced loading efficiency and sustained release of doxorubicin from hyaluronic acid/graphene oxide composite hydrogels by a mussel-inspired catecholamine. J. Nanosci. Nanotechnol. 2014, 14, 7395-7401. [CrossRef] [PubMed]

54. Shin, J.; Choi, E.J.; Cho, J.H.; Cho, A.N.; Jin, Y.; Yang, K.; Song, C.; Cho, S.W. Three-dimensional electroconductive hyaluronic acid hydrogels incorporated with carbon nanotubes and polypyrrole by catechol-mediated dispersion enhance neurogenesis of human neural stem cells. Biomacromolecules 2017, 18, 3060-3072. [CrossRef]

55. Li, X.; Cui, T.; Zhang, W.; Zhai, Z.; Wu, F.; Zhang, Y.; Yang, M.; Zhong, W.; Yue, W. Dopamine-functionalized hyaluronic acid microspheres for effective capture of CD44-overexpressing circulating tumor cells. Colloids Surf. B Biointerfaces 2020, $196,111281$. [CrossRef]

56. Ryu, J.; Kim, S.; Oh, I.; Kato, S.; Kosuge, T.; Sokolova, A.V.; Lee, J.; Otsuka, H.; Sohn, D. Internal structure of hyaluronic acid hydrogels controlled by iron(III) ion-catechol complexation. Macromolecules 2019, 52, 6502-6513. [CrossRef]

57. Wang, D.; Xu, P.; Wang, S.; Li, W.; Liu, W. Rapidly curable hyaluronic acid-catechol hydrogels inspired by scallops as tissue adhesives for hemostasis and wound healing. Eur. Polym. J. 2020, 134, 109763. [CrossRef]

58. Guo, Z.; Mi, S.; Sun, W. The multifaceted nature of catechol chemistry: Bioinspired pH-initiated hyaluronic acid hydrogels with tunable cohesive and adhesive properties. J. Mater. Chem. B 2018, 6, 6234-6244. [CrossRef]

59. Guo, Z.; Mi, S.; Sun, W. A facile strategy for preparing tough, self-healing double-network hyaluronic acid hydrogels inspired by mussel cuticles. Macromol. Mater. Eng. 2019, 304, 1800715. [CrossRef]

60. Lee, S.; Kim, S.; Park, J.; Lee, J.Y. Universal surface modification using dopamine-hyaluronic acid conjugates for anti-biofouling. Int. J. Biol. Macromol. 2020, 151, 1314-1321. [CrossRef]

61. Kim, T.G.; Lee, Y.; Park, T.G. Controlled gene-eluting metal stent fabricated by bio-inspired surface modification with hyaluronic acid and deposition of DNA/PEI polyplexes. Int. J. Pharm. 2010, 384, 181-188. [CrossRef] [PubMed]

62. Zhang, S.; Hou, J.; Yuan, Q.; Xin, P.; Cheng, H.; Gu, Z.; Wu, J. Arginine derivatives assist dopamine-hyaluronic acid hybrid hydrogels to have enhanced antioxidant activity for wound healing. Chem. Eng. J. 2020, 392, 123775. [CrossRef]

63. Pornpitchanarong, C.; Rojanarata, T.; Opanasopit, P.; Ngawhirunpat, T.; Patrojanasophon, P. Catechol-modified chitosan/hyaluronic acid nanoparticles as a new avenue for local delivery of doxorubicin to oral cancer cells. Colloids Surf. B Biointerfaces 2020, 196, 111279. [CrossRef] [PubMed]

64. Lee, Y.; Lee, H.; Messersmith, P.B.; Park, T.G. A bioinspired polymeric template for 1D assembly of metallic nanoparticles, semiconductor quantum dots, and magnetic nanoparticles. Macromol. Rapid. Commun. 2010, 31, 2109-2114. [CrossRef] 
65. Lee, J.; Yoo, K.C.; Ko, J.; Yoo, B.; Shin, J.; Lee, S.J.; Sohn, D. Hollow hyaluronic acid particles by competition between adhesive and cohesive properties of catechol for anticancer drug carrier. Carbohydr. Polym. 2017, 164, 309-316. [CrossRef]

66. Xu, W.; Qian, J.; Hou, G.; Suo, A.; Wang, Y.; Wang, J.; Sun, T.; Yang, M.; Wan, X.; Yao, Y. Hyaluronic acid-functionalized gold nanorods with $\mathrm{pH} / \mathrm{NIR}$ dual-responsive drug release for synergetic rargeted photothermal chemotherapy of breast cancer. ACS Appl. Mater. Interfaces 2017, 9, 36533-36547. [CrossRef]

67. Zhang, X.; Li, Z.; Yuan, X.; Cui, Z.; Yang, X. Fabrication of dopamine-modified hyaluronic acid/chitosan multilayers on titanium alloy by layer-by-layer self-assembly for promoting osteoblast growth. Appl. Surf. Sci. 2013, 284, 732-737. [CrossRef]

68. Wang, Z.; Chen, Z.; Liu, Z.; Shi, P.; Dong, K.; Ju, E.; Ren, J.; Qu, X. A multi-stimuli responsive gold nanocage-hyaluronic platform for targeted photothermal and chemotherapy. Biomaterials 2014, 35, 9678-9688. [CrossRef]

69. Almeida, A.C.; Vale, A.C.; Reis, R.L.; Alves, N.M. Bioactive and adhesive properties of multilayered coatings based on catecholfunctionalized chitosan/hyaluronic acid and bioactive glass nanoparticles. Int. J. Biol. Macromol. 2020, 157, 119-134. [CrossRef]

70. Joo, H.; Byun, E.; Lee, M.; Hong, Y.; Lee, H.; Kim, P. Biofunctionalization via flow shear stress resistant adhesive polysaccharide, hyaluronic acid-catechol, for enhanced in vitro endothelialization. J. Ind. Eng. Chem. 2016, 34, 14-20. [CrossRef]

71. Oh, Y.J.; Cho, I.H.; Lee, H.; Park, K.J.; Lee, H.; Park, S.Y. Bio-inspired catechol chemistry: A new way to develop a re-moldable and injectable coacervate hydrogel. Chem. Commun. 2012, 48, 11895-11897. [CrossRef] [PubMed]

72. Sato, T.; Aoyagi, T.; Ebara, M.; Auzely-Velty, R. Catechol-modified hyaluronic acid in situ-forming hydrogels by auto-oxidation of catechol or photo-oxidation using visible light. Polym. Bull. 2017, 74, 4069-4085. [CrossRef]

73. Lee, J.; Yang, S.H.; Hong, S.P.; Hong, D.; Lee, H.; Lee, H.Y.; Kim, Y.G.; Choi, I.S. Chemical control of yeast cell division by cross-linked shells of catechol-grafted polyelectrolyte multilayers. Macromol. Rapid. Commun. 2013, 34, 1351-1356. [CrossRef] [PubMed]

74. Zhang, T.-D.; Deng, X.; Wang, Y.-F.; Wang, X.-T.; Zhang, X.; Chen, L.-L.; Cao, X.; Zhang, Y.-Z.; Zhang, C.-Y.; Zheng, X.; et al. Layer-by-layer coating of polyvinylamine and dopamine-modified hyaluronic acid inhibits the growth of bacteria and tumor cell lines on the surface of materials. Appl. Surf. Sci. 2020, 530, 147197. [CrossRef]

75. Almeida, A.C.; Vale, A.C.; Pires, R.A.; Reis, R.L.; Alves, N.M. Layer-by-layer films based on catechol-modified polysaccharides produced by dip- and spin-coating onto different substrates. J. Biomed. Mater. Res. B 2020, 108, 1412-1427. [CrossRef]

76. Song, I.T.; Lee, M.; Lee, H.; Han, J.; Jang, J.H.; Lee, M.S.; Koh, G.Y.; Lee, H. PEGylation and HAylation via catechol: Alpha-Aminespecific reaction at N-terminus of peptides and proteins. Acta Biomater. 2016, 43, 50-60. [CrossRef]

77. Lu, B.; Luo, D.; Zhao, A.; Wang, H.; Zhao, Y.; Maitz, M.F.; Yang, P.; Huang, N. pH responsive chitosan and hyaluronic acid layer by layer film for drug delivery applications. Prog. Org. Coat. 2019, 135, 240-247. [CrossRef]

78. Kang, E.B.; Lee, G.B.; In, I.; Park, S.Y. pH-sensitive fluorescent hyaluronic acid nanogels for tumor-targeting and controlled delivery of doxorubicin and nitric oxide. Eur. Polym. J. 2018, 101, 96-104. [CrossRef]

79. Shin, J.; Choi, S.; Kim, J.H.; Cho, J.H.; Jin, Y.; Kim, S.; Min, S.; Kim, S.K.; Choi, D.; Cho, S.W. Tissue tapes - Phenolic hyaluronic acid hydrogel patches for off-the-shelf therapy. Adv. Funct. Mater. 2019, 29, 1903863. [CrossRef]

80. Abdullah Al, N.; Lee, J.E.; In, I.; Lee, H.; Lee, K.D.; Jeong, J.H.; Park, S.Y. Target delivery and cell imaging using hyaluronic acid-functionalized graphene quantum dots. Mol. Pharm. 2013, 10, 3736-3744. [CrossRef]

81. Lee, Y.; Lee, H.; Kim, Y.B.; Kim, J.; Hyeon, T.; Park, H.; Messersmith, P.B.; Park, T.G. Bioinspired surface immobilization of hyaluronic acid on monodisperse magnetite nanocrystals for targeted cancer imaging. Adv. Mater. 2008, 20, 4154-4157. [CrossRef] [PubMed]

82. Hong, S.H.; Kim, S.; Park, J.P.; Shin, M.; Kim, K.; Ryu, J.H.; Lee, H. Dynamic bonds between boronic acid and alginate: Hydrogels with stretchable, self-healing, stimuli-responsive, remoldable, and adhesive properties. Biomacromolecules 2018, 19, $2053-2061$. [CrossRef]

83. Hong, S.H.; Shin, M.; Park, E.; Ryu, J.H.; Burdick, J.A.; Lee, H. Alginate-boronic acid: pH-triggered bioinspired glue for hydrogel assembly. Adv. Funct. Mater. 2019, 30, 1908497. [CrossRef]

84. Lee, M.; Kim, Y.; Ryu, J.H.; Kim, K.; Han, Y.M.; Lee, H. Long-term, feeder-free maintenance of human embryonic stem cells by mussel-inspired adhesive heparin and collagen type I. Acta Biomater. 2016, 32, 138-148. [CrossRef] [PubMed]

85. Ryou, M.H.; Kim, J.; Lee, I.; Kim, S.; Jeong, Y.K.; Hong, S.; Ryu, J.H.; Kim, T.S.; Park, J.K.; Lee, H.; et al. Mussel-inspired adhesive binders for high-performance silicon nanoparticle anodes in lithium-ion batteries. Adv. Mater. 2013, 25, 1571-1576. [CrossRef]

86. Zhou, D.; Li, S.; Pei, M.; Yang, H.; Gu, S.; Tao, Y.; Ye, D.; Zhou, Y.; Xu, W.; Xiao, P. Dopamine-modified hyaluronic acid hydrogel adhesives with fast-forming and high tissue adhesion. ACS Appl. Mater. Interfaces 2020, 12, 18225-18234. [CrossRef]

87. Jooybar, E.; Abdekhodaie, M.J.; Alvi, M.; Mousavi, A.; Karperien, M.; Dijkstra, P.J. An injectable platelet lysate-hyaluronic acid hydrogel supports cellular activities and induces chondrogenesis of encapsulated mesenchymal stem cells. Acta. Biomater. 2019, 83, 233-244. [CrossRef]

88. Yuan, J.; Maturavongsadit, P.; Metavarayuth, K.; Luckanagul, J.A.; Wang, Q. Enhanced bone defect repair by polymeric substitute fillers of multiarm polyethylene glycol-crosslinked hyaluronic acid hydrogels. Macromol. Biosci. 2019, 19, e1900021. [CrossRef]

89. Tsou, Y.H.; Khoneisser, J.; Huang, P.C.; Xu, X. Hydrogel as a bioactive material to regulate stem cell fate. Bioact. Mater. 2016, 1, 39-55. [CrossRef]

90. Schweigert, N.; Zehnder, A.J.B.; Eggen, R.I.L. Chemical properties of catechols and their molecularmodes of toxic action in cells, from microorganismsto mammals. Environ. Microbiol. 2001, 3, 81-91. [CrossRef]

91. Wilker, J.J. The iron-fortified adhesive system of marine mussels. Angew. Chem. Int. Ed. 2010, 49, 8076-8078. [CrossRef] [PubMed] 
92. Holten-Andersen, N.; Harrington, M.J.; Birkedal, H.; Lee, B.P.; Messersmith, P.B.; Lee, K.Y.C.; Waite, J.H. pH-induced metal-ligand cross-links inspired by mussel yield self-healing polymer networks with near-covalent elastic moduli. Proc. Natl. Acad. Sci. USA 2011, 108, 2651-2655. [CrossRef] [PubMed]

93. Barrett, D.G.; Fullenkamp, D.E.; He, L.; Holten-Andersen, N.; Lee, K.Y.; Messersmith, P.B. pH-Based regulation of hydrogel mechanical properties through mussel-inspired chemistry and processing. Adv. Funct. Mater. 2013, 23, 1111-1119. [CrossRef] [PubMed]

94. Harrington, M.J.; Masic, A.; Holten-Andersen, N.; Waite, J.H.; Fratzl, P. Iron-clad fibers: A metal-based biological strategy for hard flexible coatings. Science 2010, 328, 216-220. [CrossRef] [PubMed]

95. Zeng, H.; Hwang, D.S.; Israelachvili, J.N.; Waite, J.H. Strong reversible $\mathrm{Fe}^{3+}$-mediated bridging between dopa-containing protein films in water. Proc. Natl. Acad. Sci. USA 2010, 107, 12850-12853. [CrossRef] [PubMed]

96. Sever, M.J.; Weisser, J.T.; Monahan, J.; Srinivasan, S.; Wilker, J.J. Metal-mediated cross-linking in the generation of a marine-mussel adhesive. Angew. Chem. Int. Ed. 2004, 43, 448-450. [CrossRef] [PubMed] 